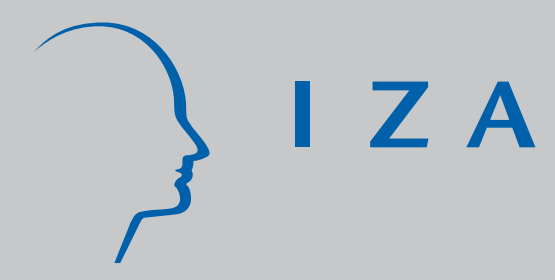

IZA DP No. 1402

The Dispersion of Employees' Wage Increases and Firm Performance

Christian Grund

Niels Westergaard-Nielsen

November 2004 


\title{
The Dispersion of Employees' Wage Increases and Firm Performance
}

\author{
Christian Grund \\ University of Bonn, \\ CCP and IZA Bonn
}

Niels Westergaard-Nielsen

CCP, Aarhus School of Business

and IZA Bonn

\section{Discussion Paper No. 1402 \\ November 2004}

\author{
IZA \\ P.O. Box 7240 \\ 53072 Bonn \\ Germany \\ Phone: +49-228-3894-0 \\ Fax: +49-228-3894-180 \\ Email: iza@iza.org
}

Any opinions expressed here are those of the author(s) and not those of the institute. Research disseminated by IZA may include views on policy, but the institute itself takes no institutional policy positions.

The Institute for the Study of Labor (IZA) in Bonn is a local and virtual international research center and a place of communication between science, politics and business. IZA is an independent nonprofit company supported by Deutsche Post World Net. The center is associated with the University of Bonn and offers a stimulating research environment through its research networks, research support, and visitors and doctoral programs. IZA engages in (i) original and internationally competitive research in all fields of labor economics, (ii) development of policy concepts, and (iii) dissemination of research results and concepts to the interested public.

IZA Discussion Papers often represent preliminary work and are circulated to encourage discussion. Citation of such a paper should account for its provisional character. A revised version may be available directly from the author. 
IZA Discussion Paper No. 1402

November 2004

\section{ABSTRACT \\ The Dispersion of Employees' Wage Increases and Firm Performance}

In this contribution we examine the interrelation between intra-firm wage increases and firm performance. Previous studies have focused on the dispersion of wages in order to examine for the empirical dominance of positive monetary incentives effects compared to adverse effects due to fairness considerations. We argue that the dispersion of wage increases rather than wage levels is a crucial measure for monetary incentives in firms. The larger the dispersion of wage increases the higher the amount of monetary incentives in firms. In contrast, huge wage inequality without any promotion possibilities does not induce any monetary incentives. Evidence from unique Danish linked employer employee data shows that large dispersion of wage growth within firms is generally connected with low firm performance. The results are mainly driven by white collar rather than blue collar workers.

JEL Classification: M52, J31, L25

Keywords: fairness, firm performance, inequality, monetary incentives, wage dispersion, wage increases

Corresponding author:

Christian Grund

Department of Business and Economics

BWL II

University of Bonn

Adenauerallee 24-42

53113 Bonn

Germany

Email: christian.grund@uni-bonn.de 


\section{Introduction}

In recent years, the fundamental debate has been ongoing, whether monetary incentives have a positive impact on organizations. Both theoretical arguments and empirical evidence are ambiguous. Probably, it is unchallenged that monetary incentives affect individuals' behavior. However, monetary incentives often lead to uneven outcomes among the affected individuals. This is particularly the case in tournament structures, where individuals are necessarily divided into winners and losers (see Lazear \& Rosen 1981, Rosen 1986). Tournaments are automatically ingredients of common internal labor markets. ${ }^{1}$ While the winner of a promotion tournament is promoted and receives a wage increase, for example, other employees miss out. Several approaches argue that this inequality can lead to some kind of opposed effects besides to the positive incentive effect, e.g. because of equity or fairness considerations. Not surprisingly, there is explicit evidence for both: On the one hand, monetary incentives matter (Lazear 2000) and individual efforts are affected by the prize structure of tournaments (Abrevaya 2002, Becker \& Huselid 1992, Bull, Schotter \& Weigelt 1987, Ehrenberg \& Bognanno 1990, Main, O'Reilly \& Wade 1993). On the other hand, fairness considerations influence human behavior as well (Camerer/Thaler 1995, Cowherd/Levine 1992, Güth/Schmittberger/Tietz 1990). In a series of experiments on different incentive schemes Harbring (2004) provides evidence for both.

Knowledge about the interplay of the two effects is very important when creating an efficient compensation policy in firms. A beneficial policy will always depend on the relative relevance of the two effects. Prior studies argue that the wage dispersion in firms represents the amount of monetary incentives. Some of these contributions

\footnotetext{
${ }^{1}$ Lazear (1992), Baker, Gibbs \& Holmstrom (1994a, 1994b) and Treble, van Gameren, Bridges \& Barmby (2001) provide evidence for single firms.
} 
examine the link between wage dispersion and firm performance. ${ }^{2}$ Winter-Ebmer $\&$ Zweimüller (1999) argue in a neoclassical sense that a high wage level in a firm reflects high firm performance. For white collar employees they find an inversely u-shaped interrelation between wage dispersion and the level of wages in Austrian firms. Bloom (1999) uses data from the major league baseball and shows that the level of wage dispersion among team members is negatively related to different measures of individual and team performance. Pfeffer \& Langton (1993) find decreasing research productivity and collaboration among college and university faculty with increasing wage dispersion. Some contributions focus on wage dispersion among the managers of firms only. Eriksson (1999) finds evidence for a positive relationship between the pay spread among managers and firm profitability in Denmark. However, O’Reilly, Main \& Crystal (1988) and Leonard (1990) do not confirm this result for large U.S. firms. Due to lack of better data Beaumont \& Harris (2003) use the ratio of non-manual and manual labor costs per employee as a proxy for wage dispersion in firms. This somewhat rough measure is positively related to value added per employee in the majority of manufacturing sectors in the UK. Using Swedish aggregate time-series data Hibbs and Locking (2000) find more positive than negative effects of wage dispersion on firms' real value added. Bingley \& Eriksson (2001) concentrate on the skewness of intra-firm wage distribution, which is found to be $\mathrm{u}$-shaped related to firm productivity in Denmark.

This brief overview shows that the evidence is mixed. We cannot demonstrate a clear interrelation (neither positive nor negative) in general. Indeed, there are considerable differences in the investigated specific labor market and the authors use different measures of both wage dispersion and firm performance. In this contribution we want to address an important additional aspect, which has been neglected in the literature so far.

\footnotetext{
${ }^{2}$ Turnover, tenure and job satisfaction are also affected by the dispersion of wages (see Pfeffer \& DavisBlake 1992, Pfeffer \& Langton 1993, Bloom \& Michel 2002). Already Simon (1957) argues that wage policy has an impact on employee behavior.
} 
The previous studies argue that large dispersion coincides with large (tournament) incentives in firms. However, it is important to note that this is not automatically true. If there are hardly any promotion possibilities and eminent glass ceilings, employees do not face significant monetary incentives regardless of the amount of intra-firm wage inequality. Indeed, Leonard (1990) provides evidence for the U.S. that steeper pay differentials across hierarchies are associated with lower promotion rates. Employees realize possible lacking extraordinary wage increases as well. For example, the U.S. pharmaceutical company Merck \& Co., Inc. has had an absolute performance evaluation system until the mid 80 s of the last century, which lead to strong managerial tendencies to assign uniform ratings, which again have been responsible for uniform pay increases. Thus, employees were complaining about missing incentives, when asked to judge the performance evaluation system: "What's the use of killing yourself [ ... if] you still get the same 5\% increase. It's demoralizing and demotivating" (see Murphy 1992, p. 39).

Hence, what really matters in terms of monetary incentives is not the simple dispersion of wages but rather the possibility of receiving extraordinary wage increases. First, there might be some kind of pay for performance contracts, which reward employees with respect to firm performance. But then, automatically the free riding problem occurs if employees have to bear their cost of effort, but only receive a small fraction of the surplus. From a strict economic point of view, it is rather the dispersion of wage increases which is supposed to induce additional incentives to exert effort.

From a tournament perspective the dispersion of wage increases - measured with the standard deviation - is maximized, when half of the contestants receive the winner prize. Indeed, experimental evidence hints that employees' maximal efforts occur at a 
fraction of winner prizes of 0.5 compared to tournaments with only few winner or loser prizes (see Orrison, Schotter \& Weigelt 1997, Harbring \& Irlenbusch 2004). ${ }^{3}$

On the other hand, fairness or equity considerations have to be taken into account again. Even having accepted a certain wage inequality as equitable, it might very well be the case that employees judge very uneven wage increases as unfair. Possible reactions are again reducing future effort or quitting due to demotivation. In experimental settings relevance of the participation constraint is usually neglected and the duration is limited at best to few hours. Hence, the transferability to real world business it not guaranteed with certainty. Levine (1993) asked real world compensation executives about recommendations for wage changes in a hypothetical company and certain scenarios. Indeed, the managers were concerned about giving employees different relative wage increases due to fairness aspects. Concordantly the interviews conducted by Bewley (1999) reveal that internal equity, internal harmony and fairness are the main reasons for a fixed formal wage structure inside firms.

In this contribution we push this idea one step further and ask, whether there is a link between the actual dispersion of wage increases and firm performance. As discussed directly above, incentive and fairness concerns predict contrary interrelations. Hence, it is an empirical question, which effect dominates in real world firms. In contrast to most other studies, which analyze only a small number of firms and/or a small fraction of the workforce, we are able to examine a large proportion of the Danish labor market. We have linked information for all employees and all larger private sector firms with at least 20 employees.

\footnotetext{
${ }^{3}$ Note that this is not automatically the result of tournament theory. From a theoretical point of view, the marginal probability to win a promotion tournament is the decisive factor to determine the effort choice of the employee. Orrison et al. (1997), as well as Harbring \& Irlenbusch (2002) derive for a tournament model with identically distributed individual error terms that effort choice is even independent of the fraction of winner prizes in a symmetric equilibrium.
} 


\section{The Wage Policy of Firms: Monetary Incentives versus Fairness}

As mentioned above tournament theory (see Lazear and Rosen 1981, Rosen 1986) predicts increasing effort levels with increasing wage premiums for winners of rankorder tournaments. Hence, this argument suggests a positive link between the inequality of wage increases and individual performance. In this case, firm performance should also be affected positively. However, one drawback of tournaments is that participants have two possibilities to increase their individual winning probabilities. They can either exert a high productive effort or a counterproductive effort (e.g. by withholding important information). If the problem of counterproductive effort or sabotage is relevant, a somewhat compressed wage structure is beneficial for the firm (see Lazear 1989). Drago \& Garvey (1998) find support for Australia that helping on the job among employees is reduced with increasing monetary incentives in tournament structures.

Other theories warn explicitly about too much wage inequality inside firms. More specifically, there are equity theory (Adams 1963), relative deprivation theory (Martin 1981), distributional justice theory (Cowherd and Levine 1992) and fairness (Akerlof 1984, Akerlof and Yellen 1990) or cohesiveness considerations (Levine 1991). In the following they are summarized by the term fairness approaches without neglecting their differences in detail. These fairness approaches point out that many employees are demotivated and reduce effort or even quit their jobs if they perceive to be paid unfairly or inequitably. ${ }^{4}$ For example, equity theory states that employees evaluate the relation of their own labor input (e.g. effort) and labor output (e.g. wages) compared to colleagues. If this relationship is perceived to be unfair, individuals will reduce effort in order to adjust this imbalance. As a consequence performance is argued to be negatively correlated with the dispersion of wage increases among employees of a firm.

\footnotetext{
${ }^{4}$ Fehr \& Schmidt (1999) integrate fairness considerations - in particular other-regarding preferences - in a theoretical economic analysis.
} 
The two strands of the literature obviously predict contrary results for the interrelation between the dispersion of wage increases and firm performance. However, the different temporal perspectives of tournament and equity approaches are usually not mentioned. Tournament theory focuses on incentives at the beginning and during the tournament. Nothing is said explicitly about things going on after the winner is found. ${ }^{5}$ Standard economic theory would state that there are simply no monetary incentives any more, if no further tournament follows directly. In contrast, equity approaches highlight the situation, when employees are already treated differently. This is the case, for instance, subsequent to a promotion tournament. Then the winner receives the prize and the loser receives nothing, although having possibly both exerted the same amount of effort. Hence, the two approaches are not mutually exclusive. ${ }^{6}$ Both effects are likely to be relevant in common corporate compensation policies.

The interplay of these two opposing effects can be clarified with a formal example: Let $D$ be the amount of dispersion with respect to wage increases. Then, $e_{\mathrm{F}}(D)=-\alpha D^{x}$ may characterize the negative fairness effect of $D$ on individuals' effort $e$, where $\alpha>0$ and $x>0$ represent the importance of this effect. We assume that there is a direct link between individuals' effort and firm performance. However, competition among employees will increase in $D$ simultaneously. Tournament theory predicts a positive interrelation of the prize spread and individual effort choice, for instance (see Lazear \& Rosen 1981). In general, this competition effect can be formalized as $e_{\mathrm{C}}(D)=\beta D^{y}$, where $\beta>0$ and $y>0$ indicate measures for its magnitude. The overall effect of the dispersion of wage increases on effort can be characterized as the sum of the two components:

\footnotetext{
${ }^{5}$ Waldman (2003) is an exemption. He focuses on the time inconsistency problem. In promotion tournaments it might ex post be rational to hire an outsider. However, this will destroy ex ante incentives for incumbents.

${ }^{6}$ Besides, recent economic approaches try to incorporate sentiments like relative deprivation, envy and compassion in tournament models as well (see Kräkel 2000, Grund and Sliwka 2004). They again choose an ex ante view and argue that employees anticipate the uneven outcomes in the future with the associated perceptions. Then the effort choice is made taking into account their anticipated inequity aversion.
} 


$$
e(\mathrm{D})=e_{\mathrm{C}}(D)+e_{\mathrm{F}}(D)=\beta D^{y}-\alpha D^{x}
$$

The gradient of this function depends on the relation between $x$ and $y$. Figure 1 visualizes the interaction of the two effects. We obtain a u-shaped interrelation for $y>x$. The minimum can be found at $(x \alpha / y \beta)^{1 /(x+y)}$. In this case, the negative fairness effect outweighs the positive competition effect for small amounts of wage increase dispersion. However, the latter dominates for high degrees of wage increase dispersion. Hence, with increasing $\alpha(\beta)$ the downward (upward) sloping interrelation matters more and more. These effects turn around for $y<x$, when a inverse u-shaped interrelation follows. For $y=x$ it depends on the size of $\alpha$ and $\beta$, whether it results in a strict increasing or decreasing interrelation. ${ }^{7}$ As argued above, there are arguments for different possible gradients. It is, however, an empirical question, which effect dominates in practice. Until now, there is no empirical insight about this issue.

Insert Figure 1 about here

We will study this interrelation in the following empirical examination. Regressing the dispersion of wage increases and its square on firm performance, we can examine the gradient of the relationship and calculate a possible minimum or maximum of the function. Then we can check, whether there is a positive or negative relationship between the dispersion of wage increases and firm performance for the majority of firms.

\footnotetext{
${ }^{7}$ Strict increasing (decreasing) interrelations can also be generated by setting $x=0(y=0)$.
} 


\section{Wage I ncrease Dispersion and Performance of Danish Firms}

\subsection{Data und Methodology}

The data used in this study originates from two sources: The first is the Statistics Denmark IDA (Integrated Database for Labour Market Research) Register. IDA contains information on labour market conditions for persons and workplaces in Denmark over the years 1980-1998. This data originates from various administrative registers. The important feature of IDA is that it is possible to associate workplaces with the identity of all employees at a specific day in November each year. Employers are defined by their employer identification number, which is changed if ownership changes in a strictly legal sense. We have corrected for those cases where more than $50 \%$ of all employees are taken over by the new legal employer. In these cases, the work place is said to continue.

Data on workplaces are subsequently aggregated to firms by Statistics Denmark for Center for Corporate Performance. For a subsample of firms with more than 20 employees these data have been merged with data on financial information concerning profit, total revenue, total costs, investments and capital. These data cover the period 1992-1997.

The individual data includes information on gender, age, education, occupational status and wage. For each firm and year we are able to calculate descriptive statistics (means and standard deviations) of these variables. Thus, the great advantage of our data is that we can observe not only a sample of firms and/or employees, but the whole population of both sides of the market. By aggregating the information of the employees and matching it to the firms, we receive a data set where the firm/year is the unit.

It is argued in section 2 that wage increases of employees and especially the dispersion of wage increases are the crucial objects of investigation in this study. In order to analyze wage increases, we have to restrict our data set to employees who stay in a firm for two consecutive years. A second restriction applies to the firm size. It is not very 
meaningful to calculate wage (increase) dispersions for very small firms with very few employees. Hence, we restrict our data set to firms with at least 20 employee observations in a certain year.

We measure firm performance with the log of value added per employee. Value added is thereby defined as net revenue (after rebates and after tax) less purchase of goods (freight, raw and auxiliary materials and external wages). ${ }^{8}$ The central aim of this contribution is to analyze the link between the dispersion of wage increases (wage / $^{\text {/ }}$ wage $_{t-1}$ ) and firm performance ( $\log$ of value added $(\mathrm{t})$ ). We take the coefficient of variation - which is the standard deviation divided by the mean - of individual wage increases in firms as a measure for wage increase dispersion. We use hourly gross wages as our wage variable. All values for value added and wages are deflated with the Danish Consumer Price Index with the basis of the year 1997. In order to examine possible non-linear effects of the dispersion of wage increases on firm performance, which were suggested by the considerations of section 2 and Figure 1, we also make use of the square of the coefficient of variation.

Other variables are supposed to affect value added as well. Wages have still to be paid by value added. Hence, a positive interrelation is expected. In order to have a link to previous studies, we also have a look at the effect of the dispersion of the firms' wage level next to the dispersion of wage increases. Additionally, the average age of employees and the dispersion of employees' ages might have an effect. Lazear (1998, pp. 169ff) argues that there are usually complementarities among the different kinds of human capital of young and old workers. Young employees have new ideas and skills on new technologies, whereas the elderly have knowledge about the intra-firm structures and the relevant markets and networks. Usually both kinds of human capital are necessary for firm productivity. ${ }^{9}$ Hence, a mixture of age groups seems to be beneficial, although communication problems among the age groups might arise.

\footnotetext{
${ }^{8}$ See Hibbs and Locking (2000) as well as Beaumont and Harris (2001) for studies which use also value added as a performance indicator.

${ }^{9}$ A second argument for having different age groups in a company comes from overlapping generations models. Cremer (1986) shows that an overlapping generations structure with several age cohorts can be a decisive factor to induce cooperation among employees who forbear from shirking in prisoner dilemma situations.
} 
Additional control variables are education level of the workforce, percentage females, percentage blue collars, firm size and branch of industry.

We have deleted some outliers with extremely high respectively low value added per employee. Also firms with extreme variations in the numbers of employees and extreme fraction of leavers are not taken into account. Additionally, we delete the top managers of the firms since we also want to examine the influence of the subgroups of blue collar and white collar workers. The results are robust with respect to all of these limitations. The data set results in some 22,000 observations. During the six year period (1992 1997) there is information about 5,736 different firms. Some descriptive statistics are given in Table 1. The mean value added per employee amounts to some 400,000 DKK, which equates with around 70,000 US $\$$ or $60,000 €$. The descriptive statistics are reasonably stable over the observation period 1992 to 1997. In particular, the dispersion of wage levels and wage increases in firms does not deviate very much.

Insert Table 1 about here

Referring to the previous studies, we start our multivariate analysis by regressing only the dispersion of the wage levels next to the control variables on the log of value added. First, we use simple OLS to examine differences between firms. Taking into account unobserved heterogeneity, we continue to estimate fixed effects panel regressions. In a second step we include the dispersion of wage increases and its square as explanatory variables. Further on, we split the firms' workforce and examine whether unequal wage increases among blue and/or white collar workers are interrelated to firm performance. In addition to other robustness checks, we also take a look on lead effects. 


\subsection{Results}

First of all, it is not surprising that the mean wage in firms is positively related to value added since wages are still to be paid from value added. The regression models (1) and (2) of Table 2 can be characterized as a revision of the cited literature on the link between wage dispersion and firm performance. As mentioned above, there is some evidence in the literature for both a positive and negative context. The OLS regression (model 1) shows that value added is highest for firms with intermediate levels of wage dispersion. However, there is considerable unobserved heterogeneity across firms. The firm fixed effects estimation (model 2) reveals that there is no causal effect. That does not mean that we repudiate possible effects - neither positive nor negative - for clear delimited parts of the labor market, which has been shown by previous studies. However, on aggregate we cannot find a significant interrelation of wage dispersion and firm performance.

Model (3) and (4) integrate the dispersion of wage growth and its square. The results with respect to the other independent variables are not affected dramatically. There is a $\mathrm{u}$-shaped link between wage growth dispersion and firm performance across firms. This result does also hold for the fixed effects estimation (model 4). Up to a minimum for the coefficient of variation of wage growth at about 0.6 the interrelation is negative. Hence, in this range the effect of increasing incentives is dominated by fairness considerations. However, when monetary incentives become stronger and stronger (and fairness considerations are not important any more anyway), we should expect a positive relation with value added from a certain point on. Indeed, for values greater than 0.6 we find a positive link. However, the vast majority of firms (98\%) have dispersions of wage increases of less than 0.6. Hence, marginal increases are associated with reductions of value added for the majority of firms. This is in line with experimental evidence of Eriksson and Villeval (2004) that inequality aversion among individuals reduces the attraction of performance related pay and the above cited results from interviews with managers (see Levine 1993, Bewley 1999). Revisiting Figure 1, the ushaped instead of the other possible patterns is confirmed. The supposed fairness effect is thereby dominating the opposed competition effect for the vast majority of firms. 
The results for the control variables show that there is inverse u-shaped interrelation for the percentage of female employees, the mean age and the dispersion of employees' age. In contrast, the effect for firm size is u-shaped. The percentage of blue collar workers and the education level is negatively linked to value added for given wages.

These results are robust to different specifications of the regressions and sub samples of the data. We have found the same interrelations for single industries (e.g. manufacturing, construction, and retail) and for a more expanded classification of industries and different categories of firm size. One can argue that it is not value added, but profit (defined as value added minus wage cost), what matters. Regressions on profits lead to comparable results though. Using the standard deviation instead of the coefficient of variation as the dispersion measure does not change the results, either.

Insert Table 2 about here

Often, the production process of firms is organizationally strictly separated from the administration. That is why it seems to be meaningful to look at blue collar and white collar workers separately and compute mean wages, wage dispersion and wage increase dispersion for these two groups of employees individually. In addition we check the possible interrelation of differences in the wages between both groups by taking into account their relative wage. ${ }^{10}$ Many firms are characterized by either a majority of blue collar or white collar employees. To get meaningful results we limit the data set to firms with at least 10 blue collar and 10 white collar observations in a particular year. Hence, the sample size is reduced to 11,000 observations and about 3,500 different firms.

\footnotetext{
${ }^{10}$ Note that this was the only measure of firms' wage dispersion of the study by Beaumont and Harris (2003).
} 
It turns out that the wage policy of firms does not play that crucial role for blue collar workers (see Table 3). There are no significant effects for the mean wage of blue collars, the wage dispersion among blue collars or the dispersion of blue collar workers' wage increases. Apparently, for this group of employees other aspects such as monitoring or technological conditions are more important in order to influence firm performance. The wage of white collar workers exceeds the wage of blue collars by around 20 percent on average. The amount of this wage differential has no significant effect on firm performance in Denmark. In contrast to the blue collar workers, the results for white collar employees show the same patterns as in Table 2 and thereby confirm the overall results. The effects for the dispersion of wage levels are only significant in the OLS but not in the fixed effect regression. Looking at the dispersion of wage increases among white collars, we again find a u-shaped interrelation to firm performance. Therefore, the overall results are driven by significant effects among the white collar workers.

Insert Table 3 about here

One can argue that the presented effects might be superposed by opposite effects in subsequent years. For example, less capable employees faced by increased wage growth dispersion may first reduce effort and quit their job only after a while. Firms with high wage growth dispersion may benefit from this sorting effect in the long run. To examine possible effects on longer periods, we run the same specification as model (4) of Table 2 with the value added of the subsequent year as the dependent variable. Afterwards we do it also for the second subsequent year. Doing this we loose a considerable number of observations, because information for value added is only available until 1997. It is shown that possible opposed effects such as sorting of employees across firms do not play a crucial role for the results. Again, there is a u-shaped relationship of the dispersion of wage increases on firm performance of the next period as well (see Table 
4). One additional year ahead there is no significant interrelation any more. Results for regressions on differences of log value added over consecutive year also support our results, although the level of significance decreases.

Insert Table 4 about here

\section{Conclusion}

Our study extends previous contributions on the interplay of incentive and fairness effects with respect to the wage policy of firms in at least two ways. First, we can make use of a linked employer-employee data set, which covers all employees and firms of the Danish private sector labor market. Therefore, our results do not depend on specific characteristics of particular employment relationships like in sports studies, for example. Second, contrary to previous studies, we focus on the relationship between the dispersion of wage increases (not levels) and firm performance, because this measure is argued to be a better proxy for the amount of monetary incentives in firms. Our main and robust finding is a u-shaped interrelation between wage increase dispersion in firms and firm performance. The vast majority of the firms are actually on the decreasing part of the U-curve. Therefore, fairness considerations are found to be more important than competition effects in general. The results are primarily driven by white collar rather than blue collar workers.

Based on our results, recommendations for the wage policy of firms have to include that the management has to be extremely cautious when treating employees differently, because financial losses may occur. Although a certain dispersion of wage levels is possibly perceived as fair (e.g. because of differences in human capital or tasks), this 
might not necessarily be the case for differences in wage increases. Employees seem to react extremely sensitively to the amount of wage increase dispersion. Fehr and Rockenbach (2003) report evidence from an abstract experiment that people usually cooperate to a certain extent. The degree of cooperation is affected by the possibility that certain incentives can be implemented, which are perceived as a fine. If the fine is imposed, the degree of cooperation decreases. However, the degree of cooperation is even strengthened if a fine is possible, but not imposed. Applying the result to our study, a high amount of wage increase dispersion can be perceived as a fine by inequality adverse employees. Although increasing the wage growth dispersion leads to a positive incentive or competition effect, cooperation among employees as well as between employees and management may be destroyed. In contrast, cooperation of employees seems to be highest if management consciously abstains from - principally possible - extraordinary dispersion of wage increases and communicates this to the employees in the right way. In this sense, the degree of cooperation seems to be highly correlated with firm performance.

We have not found differences between industries and firm size categories. However, the effect of the dispersion of wage increases on firm performance might depend on other used features of human resource management in firms or corporate culture. Often, the relevance of monetary incentives is associated with a high degree of monitoring in firms. In contrast, monetary incentives might be unnecessary, if the corporate culture is stamped by trust between management and subordinates (Deckop, Mangel \& Cirka 1999). Unfortunately, we are not able to distinguish firms in terms of their corporate culture. Future research is also supposed to analyze, whether our findings are robust for other institutional environments as well. It may well be the case that fairness considerations are less or even more important in other countries. The dispersion of wage increases is influenced by unions in many countries to some extent, which may influence the results. The main problem is that appropriate data sets such as the Danish one are necessary in order to make meaningful evaluations. 


\section{References}

Abrevaya, J. (2002): Ladder Tournaments and Underdogs: Lessons from Professional Bowling. Journal of Economic Behavior and Organization (47), 87-101.

Adams, J. S. (1963): Toward an Understanding of Inequity. Journal of Abnormal and Social Psychology (67), 422-436.

Akerlof, George A. (1984): Gift Exchange and Efficiency-Wage Theory: Four Views. American Economic Review (74), 79-83.

Akerlof, George A.; Janet L. Yellen (1990): The Fair Wage-Effort Hypothesis and Unemployment. Quarterly Journal of Economics (105), 255-283.

Baker, G.; Gibbs, M. and Holmström, B. (1994a): The Internal Economics of the Firm: Evidence from Personnel Data. Quarterly Journal of Economics (109), 881-919.

Baker, G.; Gibbs, M. and Holmström, B. (1994b): The Wage Policy of a Firm. Quarterly Journal of Economics (109), 921-955.

Beaumont, P. B.; R. I. D. Harris (2003): Internal Wage Structures and Organizational Performance. British Journal of Industrial Relations (41), 53-70.

Becker, B. E.; M. A. Huselid (1992): The Incentive Effects of Tournament Compensation Systems. Administrative Science Quarterly (37), 336-350.

Bewley, T. F. (1999): Why Wages Don’t Fall During a Recession. Cambridge.

Bingley, P.; T. Eriksson (2001): Pay Spread and Skewness - Employee Effort and Firm Productivity. Aarhus School of Business, Working Paper 01-2.

Bloom, M. (1999): The Performance Effects of Pay Dispersion on Individuals and Organizations. Academy of Management Journal (42), 25-40.

Bloom, M.; J. G. Michel (2002): The Relationship among Organizational Context, Pay Dispersion, and Managerial Turnover. Academy of Management Journal (45), 3342.

Bull, C.; A. Schotter; K. Weigelt (1987): Tournaments and Piece Rates: An Experimental Study. Journal of Political Economy (95), 1-33.

Camerer, C.; R. H. Thaler (1995): Anomalies - Ultimatums, Dictators and Manners. Journal of Economic Perspectives (9), 209-219.

Cowherd, D. M.; D. I. Levine (1992): Product Quality and Pay Equity between Lowerlevel Employees and Top Management: An Investigation of Distributional Justice Theory. Administrative Science Quarterly (37), 302-320.

Cremer, J. (1986): Cooperation in Ongoing Organizations. Quarterly Journal of Economics (101), 33-50.

Deckop, J. R.; R. Mangel, C. C. Cirka (1999): Getting More than You Pay for: Organizational Citizenship Behavior and Pay for Performance Plans. Academy of Management Journal (42), 420-428.

Drago, R. W., Garvey, G. T. (1998): Incentives for Helping on the Job - Theory and Evidence. Journal of Labor Economics (16), 1-15. 
Ehrenberg, R. G., Bognanno, M. L. (1990): Do Tournaments have Incentive Effects?. Journal of Political Economy (98), 1307-1324.

Eriksson, T. (1999): Executive Compensation and Tournament Theory: Empirical Tests on Dansh Data. Journal of Labor Economics (17), 262-280.

Eriksson, T.; M.-C. Villeval (2004): Other-Regarding Preferences and Performance Pay - An Experiment on Incentives and Sorting. IZA Discussion paper No. 1191.

Fehr, E.; B. Rockenbach (2003): Detrimental Effects of Sanctions on Human Altruism. Nature (422), 137-140.

Fehr, E.; K. M. Schmidt (1999): A Theory of Fairness, Competition and Cooperation. Quarterly Journal of Economics(114), 817-868.

Grund, C.; Sliwka, D. (2004): Envy and Compassion in Tournaments. Forthcoming in: Journal of Economics and Management Strategy.

Güth, W.; R. Schmittberger; R. Tietz (1990): Ultimatum Bargaining Behavior - A Survey and Comparison of Experimental Results. Journal of Economic Psychology (11), 417-449.

Harbring, C. (2004): Experimental Studies on Incentives in Organizations. Berlin.

Harbring, C. and Irlenbusch, B. (2004) Anreize zu produktiven und destruktiven Anstrengungen durch relative Entlohnung, Zeitschrift für betriebswirtschaftliche Forschung (56), 546-575.

Hibbs, D. A; H. Locking (2000): Wage Dispersion and Productive Efficiency: Evidence for Sweden. Journal of Labor Economics (18), 755-782.

Kräkel, Matthias (2000): Relative Deprivation in Rank-Order Tournaments. Labour Economics (7), 385-407.

Lazear, E. P. (1989): Pay Equality and Industrial Politics. Journal of Political Economy (97), 561-580.

Lazear, E. P. (1992): The Job as a Concept. In: Bruns, W. J. (ed.): Performance Measurement, Evaluation, and Incentives. Boston, 183-215.

Lazear, E. P. (1998): Personnel Economics for Mangers. Wiley, New York.

Lazear, E. P. (2000) "Performance Pay and Productivity", American Economic Review (90), 1346-1361.

Lazear, E. P.; S. H. Rosen (1981): Rank-Order Tournaments as Optimum Labor Contracts. Journal of Political Economy (89), 841-864.

Leonard, J. S. (1990): Executive Pay and Firm Performance. Industrial and Labor Relations Review (43), 13S-29S.

Levine, D. I. (1991): Cohesiveness, Productivity, and Wage Dispersion. Journal of Economic Behavior and Organization (15), 237-255.

Levine, D. I. (1993): Fairness, Markets, and Ability to Pay: Evidence from Compensation Executives. American Economic Review (83), 1241-1259.

Main, B. G.; C. A. O'Reilly III; J. Wade (1993): Top Executive Pay: Tournament or Teamwork? Journal of Labor Economics (11), 606-628. 
Martin, J. (1981): Relative Deprivation: A Theory of Distributive Injusice for an Era of Shrinking Resources. In: L.L: Cummings, B. M. Staw (eds.): Research in Organizational Behavior. Greenwich, 53-107.

Murphy, K. J. (1992): Performance Measurement and Appraisal: Motivating Managers to Identify and Reward Performance. In: Bruns, W. J. (ed.): Performance Measurement, Evaluation, and Incentives, Boston, 37-62.

O’Reilly, C. A. III; B. G. Main; G. S. Crystal (1988): CEO Compensation as a Tournament and Social Comparison: A Tale of Two Theories. Administrative Science Quarterly (33), 257-274.

Orrison, A.; Schotter, A. and Weigelt, K. (1997): On the Design of Optimal Organizations Using Tournaments: An Experimental Examination. New York University, C.V. Starr Working Papers, No. 97-26.

Pfeffer, J.; A. Davis-Blake (1992): Salary Dispersion, Location in the Salary Distribution, and Turnover among College Administrators. Industrial and Labor Relations Review (45), 753-763.

Pfeffer, J.; N. Langton (1993): The Effect of Wage Dispersion on Satisfaction, Productivity, and Work Collaboratively: Evidence from College and University Faculty. Administrative Science Quarterly (38), 382-407.

Rosen, S. (1986): Prizes and Incentives in Elimination Tournaments. American Economic Review (76), 701-715.

Simon, H. A. (1957): The Compensation of Executives. Sociometry (20), 32-35.

Treble, J., van Gameren, E.; Bridges, S. and Barmby, T. (2001): The Internal Economics of the Firm: Further Evidence from Personnel Data. Labour Economics (8), 531-552.

Waldman, M. (2003): Ex Ante Versus Ex Post Optimal Promotion Rules: The Case of Internal Promotion. Economic Inquiry (41), 27-41.

Winter-Ebmer, R.; J. Zweimüller (1999): Intra-firm Wage Dispersion and Firm Performance. KYKLOS (52), 555-572. 
Figure 1: Fairness versus competition - the interrelation between the dispersion of wage increases and individual effort
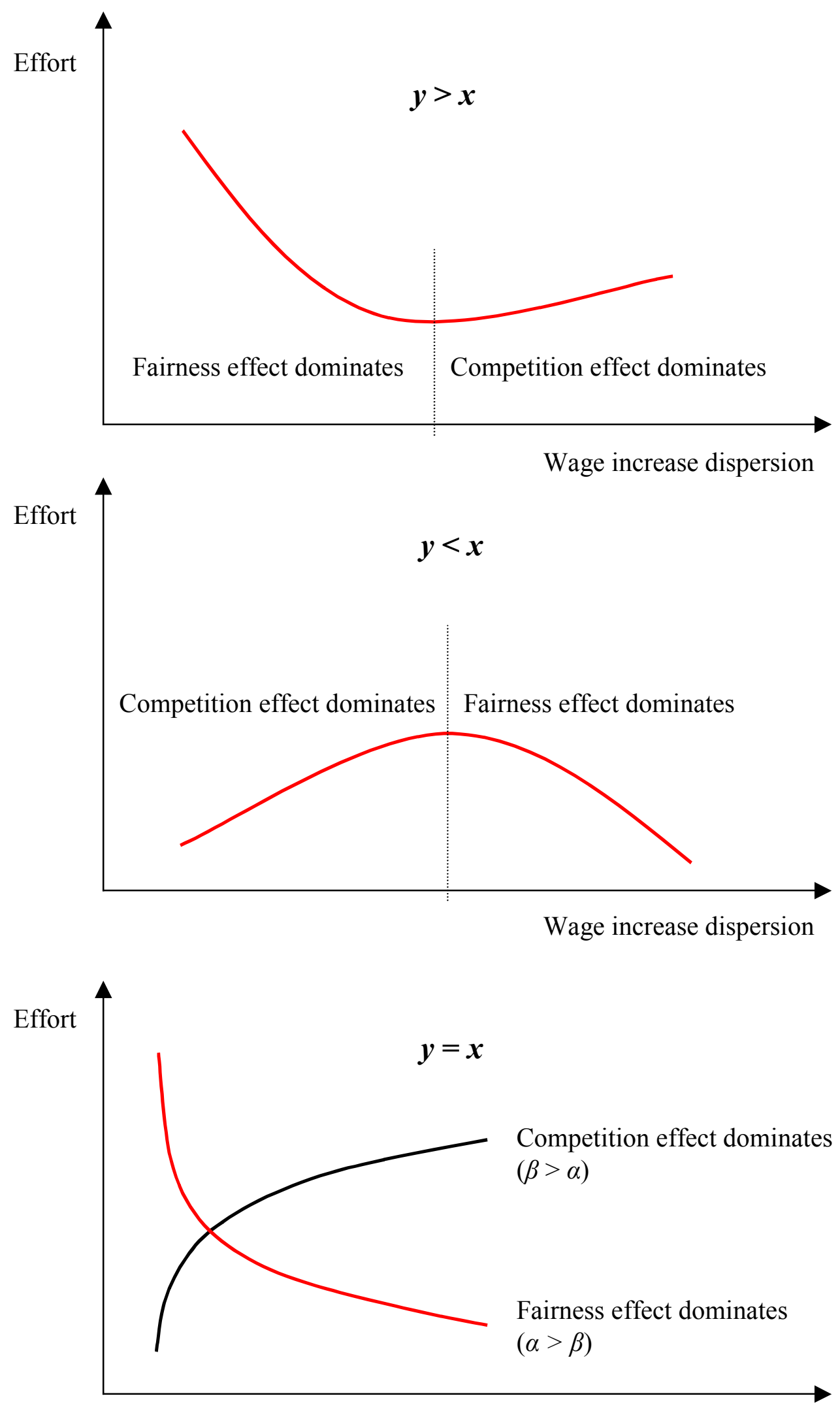

Wage increase dispersion 
Table 1: Descriptive statistics

\begin{tabular}{|c|c|c|}
\hline & \multicolumn{2}{|c|}{ Whole Sample } \\
\hline & Mean & $\begin{array}{l}\text { Standard } \\
\text { deviation }\end{array}$ \\
\hline Value added per employee (in 1,000 DKK) ${ }^{1}$ & 436.22 & 331.87 \\
\hline Percentage blue collar workers & 0.652 & 0.247 \\
\hline Percentage females & 0.269 & 0.213 \\
\hline Mean hourly wage (in DKK) ${ }^{1}$ & 155.73 & 28.77 \\
\hline Wage dispersion ${ }^{2}$ & 0.330 & 0.153 \\
\hline Dispersion of wage growth ${ }^{2}$ & 0.177 & 0.164 \\
\hline Mean education (in months) & 142.98 & 12.77 \\
\hline Dispersion of education $^{2}$ & 0.202 & 0.053 \\
\hline Mean age (in years) & 37.68 & 3.892 \\
\hline Dispersion of age $^{2}$ & 0.283 & 0.046 \\
\hline Firm size (\# employees) & 123.04 & 447.90 \\
\hline Number of observations & \multicolumn{2}{|c|}{22,178} \\
\hline
\end{tabular}

Note: ${ }^{1}$ In prices of $1997 .{ }^{2}$ Dispersion measured by coefficient of variation (= standard deviation / mean). 
Table 2: Regressions on firm performance

[Dependent variable: log (value added per employee)] ${ }^{1}$

\begin{tabular}{|c|c|c|c|c|}
\hline & $\begin{array}{c}\text { OLS } \\
(1)\end{array}$ & $\begin{array}{l}\text { Fixed } \\
\text { effects } \\
(2)\end{array}$ & $\begin{array}{l}\text { OLS } \\
(3)\end{array}$ & $\begin{array}{c}\text { Fixed effects } \\
\text { (4) }\end{array}$ \\
\hline Mean wage ${ }^{2}$ & $\begin{array}{c}0.006^{* * *} \\
(40.43)\end{array}$ & $\begin{array}{c}0.002 * * \\
(8.15)\end{array}$ & $\begin{array}{l}0.006 * * \\
(41.25)\end{array}$ & $\begin{array}{c}0.002 * * \\
(8.33)\end{array}$ \\
\hline Wage dispersion $^{3}$ & $\begin{array}{c}0.393 * * * \\
(7.78)\end{array}$ & $\begin{array}{l}-0.038 \\
(1.09)\end{array}$ & $\begin{array}{c}0.498^{* *} \\
(9.76)\end{array}$ & $\begin{array}{l}-0.021 \\
(0.58)\end{array}$ \\
\hline Wage dispersion squared & $\begin{array}{c}-0.333^{* *} \\
(9.39)\end{array}$ & $\begin{array}{l}-0.018 \\
(0.81)\end{array}$ & $\begin{array}{c}-0.358 * * \\
(10.08)\end{array}$ & $\begin{array}{r}-0.026 \\
(1.18)\end{array}$ \\
\hline Wage growth dispersion ${ }^{3}$ & ---- & ---- & $\begin{array}{c}-0.728^{* *} \\
(11.79)\end{array}$ & $\begin{array}{c}-0.121^{* *} \\
(3.36)\end{array}$ \\
\hline $\begin{array}{l}\text { Wage growth dispersion } \\
\text { squared }\end{array}$ & ---- & ---- & $\begin{array}{c}0.480 * * \\
(8.53)\end{array}$ & $\begin{array}{c}0.102 * * \\
(3.22)\end{array}$ \\
\hline Percentage blue collars & $\begin{array}{c}-0.614 * * \\
(29.33)\end{array}$ & $\begin{array}{c}-0.068^{* *} \\
(3.88)\end{array}$ & $\begin{array}{c}-0.591^{* *} \\
(28.23)\end{array}$ & $\begin{array}{c}-0.067^{* *} \\
(3.83)\end{array}$ \\
\hline Percentage females & $\begin{array}{l}0.882 * * \\
(15.95)\end{array}$ & $\begin{array}{c}0.303 * * \\
(3.39)\end{array}$ & $\begin{array}{l}0.866 * * \\
(15.72)\end{array}$ & $\begin{array}{c}0.305 * * \\
(3.40)\end{array}$ \\
\hline Percentage females squared & $\begin{array}{c}-1.305^{* *} \\
(20.19)\end{array}$ & $\begin{array}{c}-0.417^{* *} \\
(3.70)\end{array}$ & $\begin{array}{c}-1.275^{* *} \\
(19.80)\end{array}$ & $\begin{array}{c}-0.419 * * \\
(3.72)\end{array}$ \\
\hline Mean education (in months) & $\begin{array}{c}-0.005^{* *} \\
(9.37)\end{array}$ & $\begin{array}{c}-0.002^{* *} \\
(2.78)\end{array}$ & $\begin{array}{c}-0.005^{* *} \\
(9.40)\end{array}$ & $\begin{array}{c}-0.002^{* *} \\
(2.88)\end{array}$ \\
\hline Dispersion of education $^{3}$ & $\begin{array}{l}0.287 * \\
(2.49)\end{array}$ & $\begin{array}{l}-0.207 \\
(1.55)\end{array}$ & $\begin{array}{c}0.311^{* *} \\
(2.71)\end{array}$ & $\begin{array}{l}-0.205 \\
(1.54)\end{array}$ \\
\hline Mean age (in years) & $\begin{array}{c}0.058 * * \\
(5.16)\end{array}$ & $\begin{array}{c}0.027^{*} \\
(2.06)\end{array}$ & $\begin{array}{c}0.047 * * \\
(4.18)\end{array}$ & $\begin{array}{l}0.025 \\
(1.93)\end{array}$ \\
\hline Mean age squared & $\begin{array}{c}-0.001 * * \\
(5.87)\end{array}$ & $\begin{array}{c}-0.0003^{*} \\
(2.01)\end{array}$ & $\begin{array}{c}-0.001^{* *} \\
(5.09)\end{array}$ & $\begin{array}{c}-0.0003 \\
(1.91)\end{array}$ \\
\hline Dispersion of age ${ }^{3}$ & $\begin{array}{c}1.682 * * \\
(2.90)\end{array}$ & $\begin{array}{c}0.894 \\
(1.79)\end{array}$ & $\begin{array}{c}1.747^{* *} \\
(3.02)\end{array}$ & $\begin{array}{l}0.925 \\
(1.85)\end{array}$ \\
\hline Dispersion of age squared & $\begin{array}{c}-4.734 * * \\
(4.81)\end{array}$ & $\begin{array}{l}-1.571 \\
(1.84)\end{array}$ & $\begin{array}{c}-4.658 * * \\
(4.75)\end{array}$ & $\begin{array}{l}-1.591 \\
(1.86)\end{array}$ \\
\hline Firm size (\# employees) $* 100$ & $\begin{array}{c}0.007 * * \\
(6.17)\end{array}$ & $\begin{array}{c}-0.030^{* *} \\
(6.73)\end{array}$ & $\begin{array}{c}0.009 * * \\
(7.32)\end{array}$ & $\begin{array}{c}-0.029^{* *} \\
(6.59)\end{array}$ \\
\hline Firm size squared $* 1,000,000$ & $\begin{array}{c}-0.003 * * \\
(3.48)\end{array}$ & $\begin{array}{c}0.009 * * \\
(5.53)\end{array}$ & $\begin{array}{c}-0.004^{* *} \\
(4.29)\end{array}$ & $\begin{array}{c}0.009 * * \\
(5.43)\end{array}$ \\
\hline Industry dummies (5) & Yes & Yes & Yes & Yes \\
\hline Year dummies (6) & Yes & Yes & Yes & Yes \\
\hline Intercept & $\begin{array}{c}4.756^{* *} \\
(22.52)\end{array}$ & $\begin{array}{l}5.500 * * \\
(21.38)\end{array}$ & $\begin{array}{l}5.013 * * \\
(23.73)\end{array}$ & $\begin{array}{l}5.540 * * \\
(21.52)\end{array}$ \\
\hline $\mathrm{R}^{2}$ & $0.269^{4}$ & $0.035^{5}$ & $0.275^{4}$ & $0.036^{5}$ \\
\hline Number of observations & 22,178 & 22,178 & 22,178 & 22,178 \\
\hline
\end{tabular}


Table 3: Regressions on firm performance

Blue collar and white collar workers divided

[Dependent variable: log (value added per employee / 1000) ${ }^{1}$

\begin{tabular}{|c|c|c|}
\hline & $\begin{array}{l}\text { OLS } \\
\text { (1) }\end{array}$ & $\begin{array}{l}\text { Fixed } \\
\text { effects } \\
(2)\end{array}$ \\
\hline Mean blue collar wage ${ }^{2}$ & $\begin{array}{c}0.003 * * \\
(3.57)\end{array}$ & $\begin{array}{c}0.0002 \\
(0.32)\end{array}$ \\
\hline Blue collar wage dispersion ${ }^{3}$ & $\begin{array}{c}0.068 \\
(0.87)\end{array}$ & $\begin{array}{l}0.067 \\
(1.18)\end{array}$ \\
\hline Blue collar wage dispersion squared & $\begin{array}{l}-0.029 \\
(0.45)\end{array}$ & $\begin{array}{l}-0.062 \\
(1.48)\end{array}$ \\
\hline Blue collar wage growth dispersion ${ }^{3}$ & $\begin{array}{c}-0.343 * * \\
(4.70)\end{array}$ & $\begin{array}{l}-0.020 \\
(0.44)\end{array}$ \\
\hline Blue collar wage growth dispersion squared & $\begin{array}{c}0.179 * * \\
(3.30)\end{array}$ & $\begin{array}{l}0.010 \\
(0.32)\end{array}$ \\
\hline Mean white collar wage $^{2}$ & $\begin{array}{c}0.004 * * \\
(6.25)\end{array}$ & $\begin{array}{l}0.001^{*} \\
(1.99)\end{array}$ \\
\hline White collar wage dispersion ${ }^{3}$ & $\begin{array}{c}0.668 * * \\
(8.30)\end{array}$ & $\begin{array}{l}0.073 \\
(1.19)\end{array}$ \\
\hline White collar wage dispersion squared & $\begin{array}{c}-0.457^{* *} \\
(7.33)\end{array}$ & $\begin{array}{r}-0.083 \\
(1.95)\end{array}$ \\
\hline White collar wage growth dispersion ${ }^{3}$ & $\begin{array}{c}-0.443^{* *} \\
(5.51)\end{array}$ & $\begin{array}{c}-0.155^{* *} \\
(3.10)\end{array}$ \\
\hline White collar wage growth dispersion squared & $\begin{array}{c}0.302 * * \\
(4.63)\end{array}$ & $\begin{array}{c}0.127^{* *} \\
(3.28)\end{array}$ \\
\hline Mean white collar wage / mean blue collar wage & $\begin{array}{c}-0.223 * \\
(2.34)\end{array}$ & $\begin{array}{l}-0.079 \\
(1.08)\end{array}$ \\
\hline $\begin{array}{l}\text { Control for percentage blue collars, percentage females, } \\
\text { percentage females squared, mean education, dispersion of }\end{array}$ & & \\
\hline $\begin{array}{l}\text { education, mean age, mean age squared, dispersion of age, } \\
\text { dispersion of age squared, firm size, firm size squared, } \\
\text { industry dummies (5) and year dummies (6) }\end{array}$ & Yes & Yes \\
\hline Intercept & $\begin{array}{c}5.858 * * \\
(15.97)\end{array}$ & $\begin{array}{c}5.559 * * \\
(10.04)\end{array}$ \\
\hline $\mathrm{R}^{2}$ & $0.210^{4}$ & $0.027^{5}$ \\
\hline Number of observations & 11,134 & 11,134 \\
\hline
\end{tabular}

Note: Firms with at least 10 blue collar and 10 white collar employees in data. Absolute t-values in parentheses-. ${ }^{*}$ and $* *$ indicate significance at the 0.05 and 0.01 level. ${ }^{1}$ value added in 1,000 DKK. ${ }^{2}$ hourly gross wage in DKK. ${ }^{3}$ Dispersion measured by coefficient of variation (= standard deviation / mean). ${ }^{4}$ Adjusted $\mathrm{R}^{2}$ is reported. ${ }^{5}$ Within $\mathrm{R}^{2}$ is reported. 
Table 4: Wage growth dispersion and value added in $t, t+1$ and $t+2$

\begin{tabular}{lccc}
\hline & \multicolumn{3}{c}{ Fixed effects estimations } \\
& $\begin{array}{c}\text { Value added } \\
(\mathbf{t})\end{array}$ & $\begin{array}{c}\text { Value added } \\
(\mathbf{t}+\mathbf{1})\end{array}$ & $\begin{array}{c}\text { Value added } \\
(\mathbf{t}+\mathbf{2})\end{array}$ \\
\hline Wage growth dispersion & $-0.121^{* *}$ & $-0.171^{* *}$ & -0.007 \\
Wage growth dispersion squared & $(3.36)$ & $(4.15)$ & $(0.14)$ \\
Within $\mathrm{R}^{2}$ & $0.102^{* *}$ & $0.132^{* *}$ & 0.014 \\
Number of observations & $(3.22)$ & $(3.74)$ & $(0.34)$ \\
& 0.036 & 0.013 & 0.012 \\
& 22,178 & 17,689 & 13,002 \\
\hline
\end{tabular}

Note: Same specification as reported in Table 2 (model (4)). Absolute t-values in parentheses-. ** indicate significance at the 0.01 level. 